\title{
Fine sediment dynamics in the Río de la Plata
}

\author{
M. Fossati ${ }^{1}$, F. Cayocca ${ }^{2}$, and I. Piedra-Cueva ${ }^{1}$ \\ ${ }^{1}$ Instituto de Mecánica de los Fluidos e Ingeniería Ambiental (IMFIA), Uruguay \\ ${ }^{2}$ Institut Français de Recherche pour l'Exploitation de la Mer (IFREMER), France \\ Correspondence to: M. Fossati (mfossati@ fing.edu.uy)
}

Received: 11 October 2013 - Revised: 31 December 2013 - Accepted: 10 January 2014 - Published: 1 April 2014

\begin{abstract}
This paper investigates the main characteristics of the fine sediments dynamics in a very complex and extensive inner shelf area located in South America, the Río de la Plata. The results derive from a $5 \mathrm{yr}$ international research program that allowed intensive data acquisition throughout the area, as well as the development of the first numerical model investigating sediment dynamics at a regional scale in the area. The model is based on the MARS3D suite: it computes the regional tide- and wind-induced circulation, as well as sediment mixtures dynamics (erosion, advection and deposition of several sedimentary variables). Erosion due to wave action is taken into account thanks to the use of SWAN. The hydrodynamic and wave models were calibrated against several measurements in different zones of the Río de la Plata. Turbidity data (time series and vertical profiles) were then used in order to calibrate the sediment dynamics model. The model is shown to accurately reproduce the sediment concentration variability during both fair and stormy weather conditions in the intermediate and in the outer Río de la Plata. The paper also shows that the suspended sediment dynamics in the Río de la Plata is mainly driven by water/bottom exchanges.
\end{abstract}

\section{Introduction}

The Río de la Plata (RP) (Fig. 1) is one of the largest estuaries in the world, facing the Atlantic Ocean, bordering Argentina to the South and Uruguay to the North. Albeit its dimensions (280 km long and $220 \mathrm{~km}$ wide at its mouth), its water depth does not exceed $10 \mathrm{~m}$ while it exhibits both fluvial and estuarine characteristics. $9 \%$ of the continental water inputs are provided by the Paraná and Uruguay rivers with an annual mean flow of $22000 \mathrm{~m}^{3} \mathrm{~s}^{-1}$.
The RP has a complex river-estuarine-oceanic dynamics and it is classically divided into two parts separated by the topographic feature known as Barra del Indio. This transverse feature crosses the RP width between Montevideo to the North and Punta Piedras to the South; it marks the limit seaward of which both the river cross-sectional area and depth increase (Fig. 1), which also turns to be where the salinity front is located (Sepúlveda et al., 2004). The circulation is dominated by a fluvial regime with micro-tidal influence landward (in the intermediate zone), whereas the outer zone exhibits a purely micro-tidal estuarine dynamics.

The tidal regime is dominated by the M2 component, followed by the $\mathrm{O} 1$ component which is responsible for the diurnal inequality. The tidal amplitude is greater along the Argentinean coast (order of $1 \mathrm{~m}$ ), while it is about $0.4 \mathrm{~m}$ along the Uruguayan coast (Santoro et al., 2013). ADCP data registered near Montevideo city show maximum tidal currents intensities of $0.3 \mathrm{~m} \mathrm{~s}^{-1}$ near the bottom and nearly $0.5 \mathrm{~m} \mathrm{~s}^{-1}$ at the surface (Fossati and Piedra-Cueva, 2013). An important particularity of the Río de la Plata is that the meteorological tide is of the same order of magnitude as the astronomical tide; meteorological tides are mainly generated in the Argentinean continental shelf and then propagate northward as coastal trapped waves until they reach the estuary (Santoro et al., 2013).

The suspended sediment load is mainly carried by the Paraná river and amounts to 160 millions tons $\mathrm{yr}^{-1}$ of fine sand, silt and clay. Fine sands mostly settle in the Paraná discharge zone at the head of RP and are responsible for the Paraná Delta Front progradation (Menéndez and Sarubbi, 2007). Fluvial fine cohesive sediments are further advected to the inner part of the RP. Using satellite data, Framiñan and Brown (1996) concluded that the turbidity front location is related to the bottom topography: it coincides with the $5 \mathrm{~m}$ isobath at the southern coast and follows the Barra 


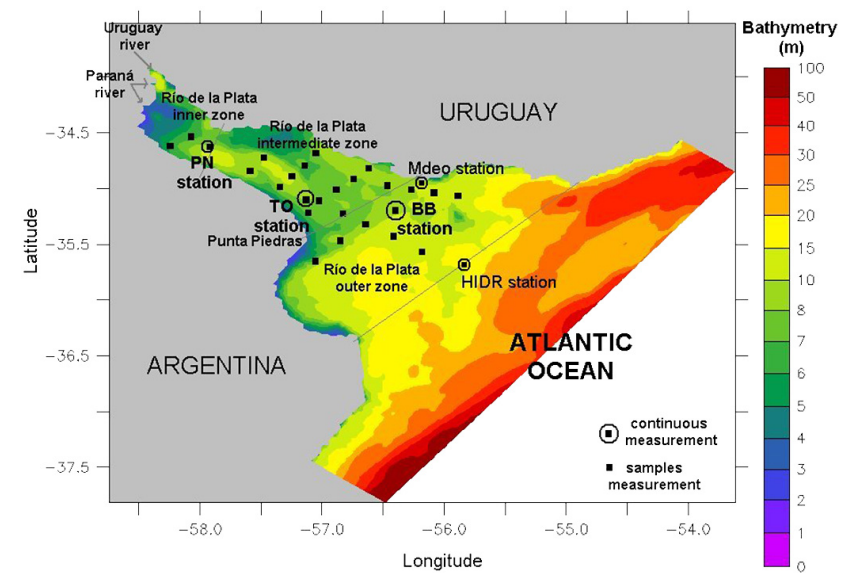

Fig. 1. Bathymetry, location, measurements stations, and zones of the Río de la Plata.

del Indio geometry across the river. Apart from this partial observation-based conclusion, the limited amount of in situ data and limited use of sediment dynamics models at the regional scale have not allowed a clear understanding of the main patterns and processes dominating the RP fine sediment dynamics so far.

\section{Objectives and methodology}

This paper investigates the main characteristics of the fine sediments dynamics in the intermediate and outer zones of the Río de la Plata. The applied methodology includes data analysis and numerical modelling (hydrodynamics calibration and sediment dynamics model adjustment).

The new data were collected during the FREPLATAIFREMER Project founded by the French Fund for the Global Environment (FFEM). The information includes hydrodynamic (temperature, salinity, water level) and turbidity time series over several months in 3 stations (PN, TO, BB, Fig. 1), current profiles and meteorological data at the $\mathrm{BB}$ station. Additionally vertical CTD profiles, turbidity profiles as well as bottom samples were acquired at 26 stations during 5 campaigns spanning 13 months (Fig. 1). They were analyzed in order to investigate the sediment parameters variability between campaigns and the spatial variability over the entire Río de la Plata.

The numerical hydrodynamic and sediment dynamics model MARS3D (Lazure and Dumas, 2008; Le Hir et al., 2011) was implemented for the area. The suspended transport for the concentration of different particle classes is computed by solving a 3-D advection-diffusion equation with bed exchange by erosion and deposition. Erosion due to wave action was taken into account thanks to the use of SWAN (Booij et al., 1999). The hydrodynamic and wave models were first calibrated against several measurements in different zones of the Río de la Plata. Turbidity data (time series and vertical

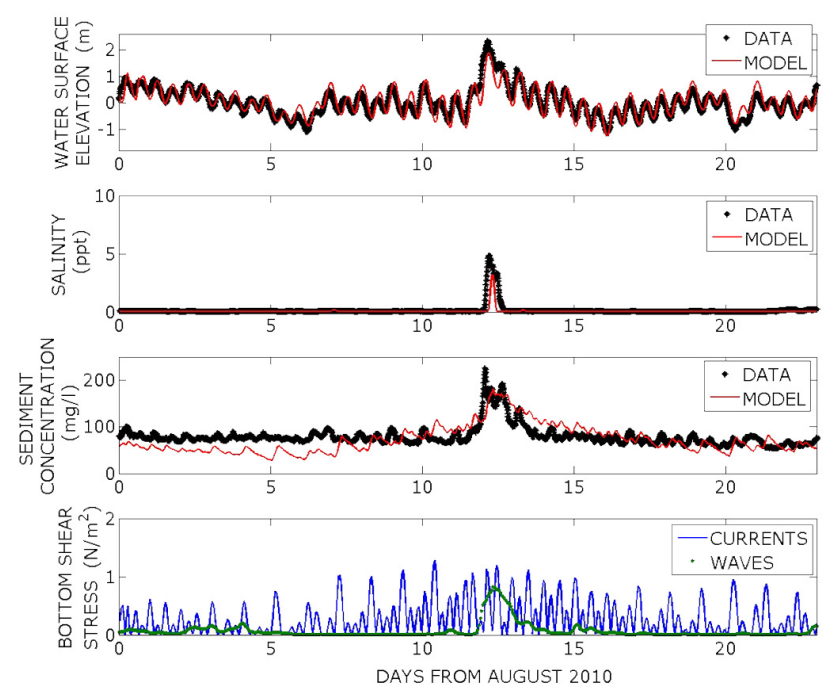

Fig. 2. Measured and modelled time series of water surface elevation (upper panel), salinity at mid depth (second panel), sediment concentration at mid depth (third panel) and computed waveinduced and current-induced bottom shear stress (lower panel) at TO station during 23 days in August 2010.

profiles) were then used in order to calibrate the sediment dynamics model. Modelling adjustment and analysis was performed during a two-year period (2009-2010).

\section{Numerical models}

MARS3D baroclinic hydrodynamic and sediment dynamics model was deployed with a $3 \mathrm{~km}$ spatial resolution configuration and 10 vertical sigma levels over the whole Río de la Plata, down to $200 \mathrm{~m}$ waterdepth offshore. This configuration takes its boundary conditions from a 2-D $10 \mathrm{~km}$ resolution configuration spanning the whole shelf from $55^{\circ} \mathrm{S}$ (Malvinas) up to $26^{\circ} \mathrm{S}$ (southern Brazil), forced by NCEP (US National Centre for Environmental Prediction) re-analysis winds (Kalnay et al., 1996) and FES2004 global model (Lyard et al., 2006), so as to take into account regional circulation. The RP 3-D model also includes as boundary conditions the measured river inputs coming from the Paraná and Uruguay rivers and the atmosphere forcing issued from $0.25^{\circ} \times 0.25^{\circ}$ ECWMF (European Centre for Medium Range Weather Forecast) winds (Dee et al., 2011).

The wave model uses the same horizontal grid and bathymetry as MARS3D model. It is forced by wave spectra at the boundary (from global WW3 runs, Ardhuin et al., 2010) and ECMWF winds accounting for water level and refraction by barotropic currents hourly updated. The hydrodynamic and wave models were calibrated against several time series for water level (Mdeo, TO and PN, Fig. 1), ADCP currents profiles (Mdeo and BB, Fig. 1), salinity (TO and BB, Fig. 1) and significant wave height (Mdeo and HIDR, Fig. 1). 


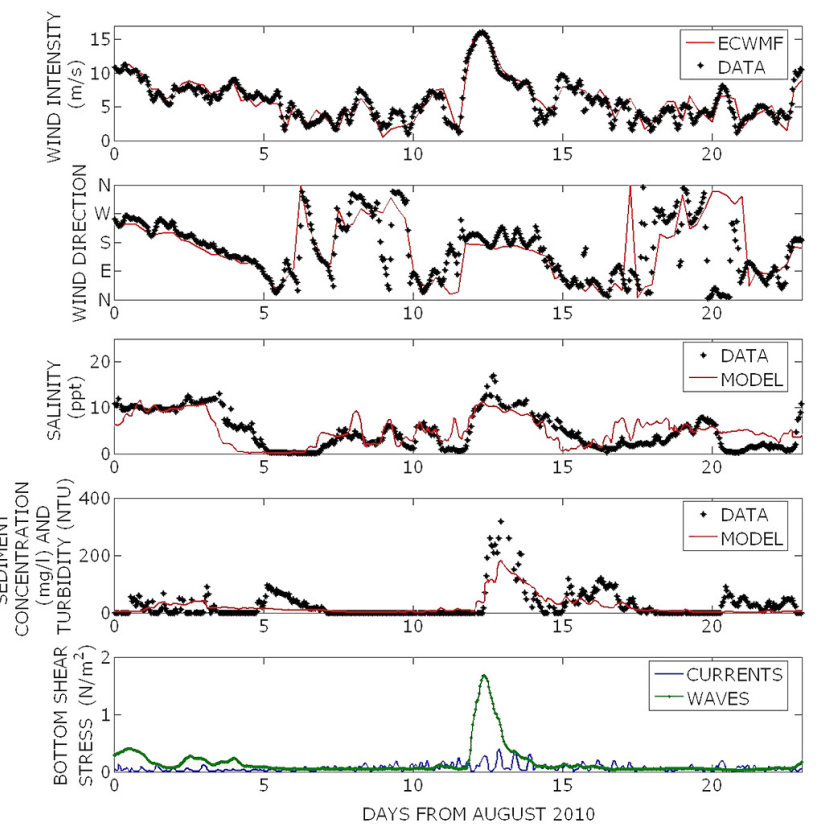

Fig. 3. Comparison between measured wind and ECWMF reanalysis (first and second panels); measured and modelled time series of mid depth salinity (third panel); mid depth measured turbidity time series and mid depth modelled sediment concentration time series (fourth panel); and computed wave-induced and currentinduced bottom shear stress (lower panel) at BB station during 23 days in August 2010.

The sediment model computes erosion rates according to Partheniades law as a function of the bottom shear stress and a critical erosion shear stress. The deposition is computed according to Krone formulation, the deposition rate being derived from the suspended sediment concentration at the bottom level, the settling velocity and a critical shear stress for deposition. The sediment settling velocity is expressed as a function of the sediment concentration so as to take into account flocculation processes (Le Hir et al., 2000).

Bottom sediment and suspended sediment samples exhibit a decrease in silt fraction and an increase in clay fraction from inner to the outer Río de la Plata. In order to include this behaviour in the model, the clay and silt sediment fractions were simulated as two different variables. The initial composition of the bottom sediment mixture was derived from historical data (López Laborde, 1997). The fluvial fine cohesive sediments load for the RP was included in the model using the mean values $150 \mathrm{mg} \mathrm{L}^{-1}$ of silt and $50 \mathrm{mg} \mathrm{L}^{-1}$ of clay. The minimum settling velocity for each variable was computed from the measured sediment particle diameter according to (Migniot, 1989) $\left(0.1 \mathrm{~mm} \mathrm{~s}^{-1}\right.$ for silt and $0.02 \mathrm{~mm} \mathrm{~s}^{-1}$ for clay).

In the initial period of the sediment model calibration, the main parameters were defined based on other MARS modeling studies (Dufois et al., 2008). Several sensitivity analyses of erosion threshold and rate, deposition thresh- old and bottom friction, were performed in order to derive a best set of model parameters. The model basically showed high sensitivity to all of them. Bottom friction was defined during hydrodynamic model calibration. Turbidity data series were used in order to calibrate the erosion and deposition parameters that highly influence the sediment dynamics model. The obtained calibrated values are a high critical bed shear stress for deposition $\left(\tau c d=1000 \mathrm{~N} \mathrm{~m}^{-2}\right)$, an erosion threshold $\tau c e=0,1 \mathrm{~N} \mathrm{~m}^{-2}$, and an erosion rate $E 0=4 \times 10^{-6} \mathrm{Kg} \mathrm{s}^{-1}$.

\section{Results}

Figure 2 shows measured and computed time series of water level, salinity and fine sediment concentration (mid depth) during a twenty day period in August 2010 in the intermediate station TO. The bottom shear stress due to bottom currents and waves is also shown. While wave induced shear stresses are much more linked to weather conditions than current induced shear stresses, they exhibit similar maximum values. Data suggest that the salinity front rarely reaches the TO station except when the Río de la Plata is hit by significant storms. In such occurrences (between 12 and 13 August, see Fig. 2), measurements show a sharp salinity increase and high water level values corresponding to the meteorological storm surge during the storm, both well represented by the hydrodynamic model. The fine sediment concentration time series exhibit values of the order of $100 \mathrm{mg} \mathrm{L}^{-1}$ during the first days of August (corresponding to fair weather conditions) and values up to $200 \mathrm{mg} \mathrm{L}^{-1}$ during the storm. The suspended concentrations promptly return to previous values right after the storm. The sediment concentration time series obtained by the calibrated model seems to reproduce the main observed behaviour for both calm and stormy conditions.

Figure 3 shows the measured and modelled wind, salinity and turbidity time series for the BB station during the same period as for the TO station. Current- and wave-induced bottom shear stresses are also shown; they suggest that tidal bottom shear stress is low at all times in the outer zone and that wave-induced bottom shear stresses during storms are several times larger than current-induced stresses. Comparison between ECWMF re-analysis winds and measured winds at the BB station show that the ECMWF representation is very reliable in the Río de la Plata area (Fig. 3). The model results show that sediment concentrations during fair weather conditions are relatively low (less than $30 \mathrm{mg} \mathrm{L}^{-1}$ in the middle of the water column) and increase during storms, up to $150 \mathrm{mg} \mathrm{L}^{-1}$. Salinity also increases as a consequence of offshore water being pushed towards the estuary by strong southerly winds. Both model salinity and fine sediment time series follow the main fluctuations observed in the time series data with some differences during non storm conditions, probably due to the hydrodynamic and wave model 


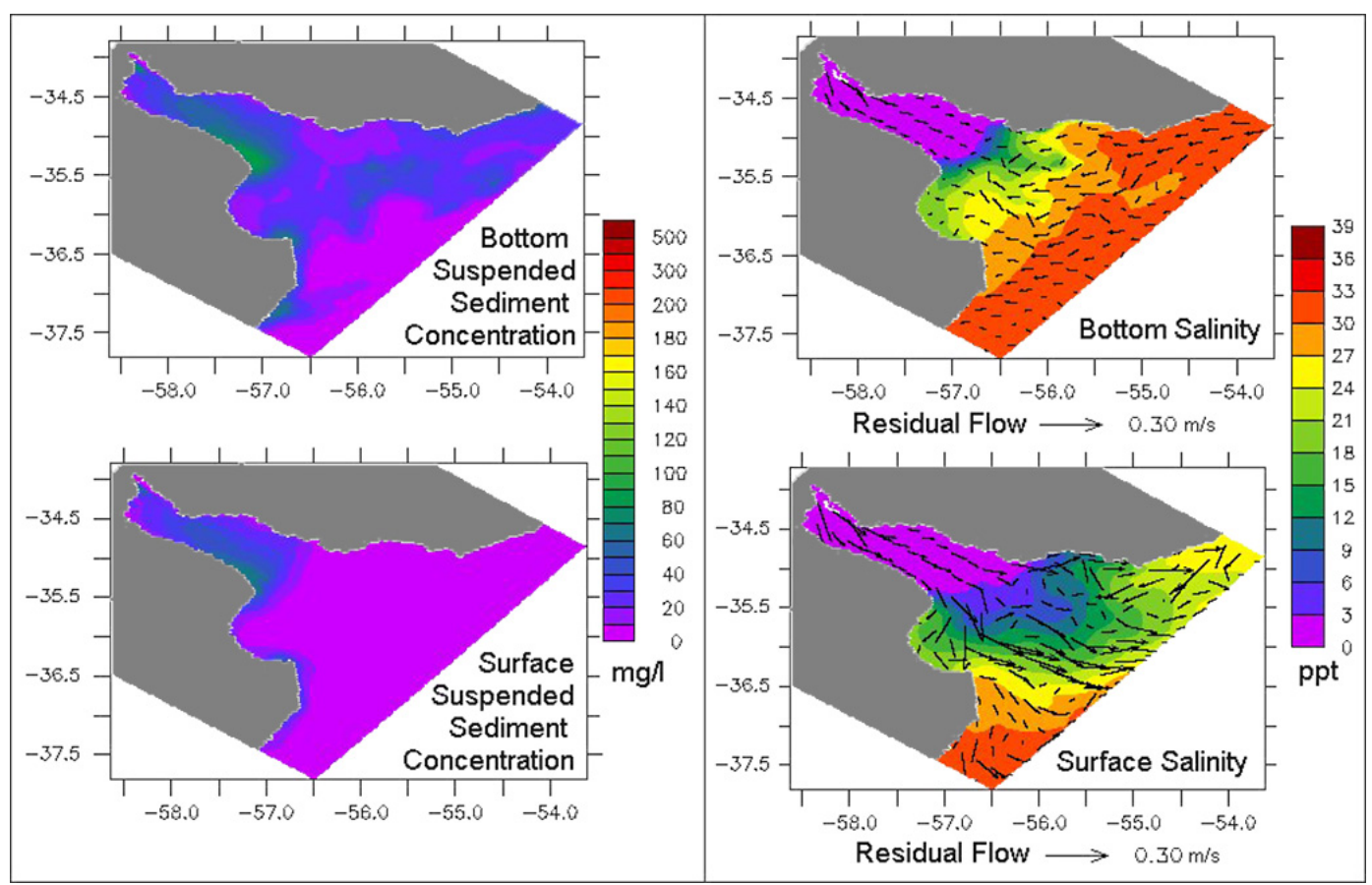

Fig. 4. Mean computed fields obtained over the 17-23 August 2010 period (fair weather conditions): bottom suspended sediment concentration (upper left panel), surface suspended sediment concentration (lower left panel), bottom salinity and residual flow (upper right panel), surface salinity and residual flow (lower right panel).

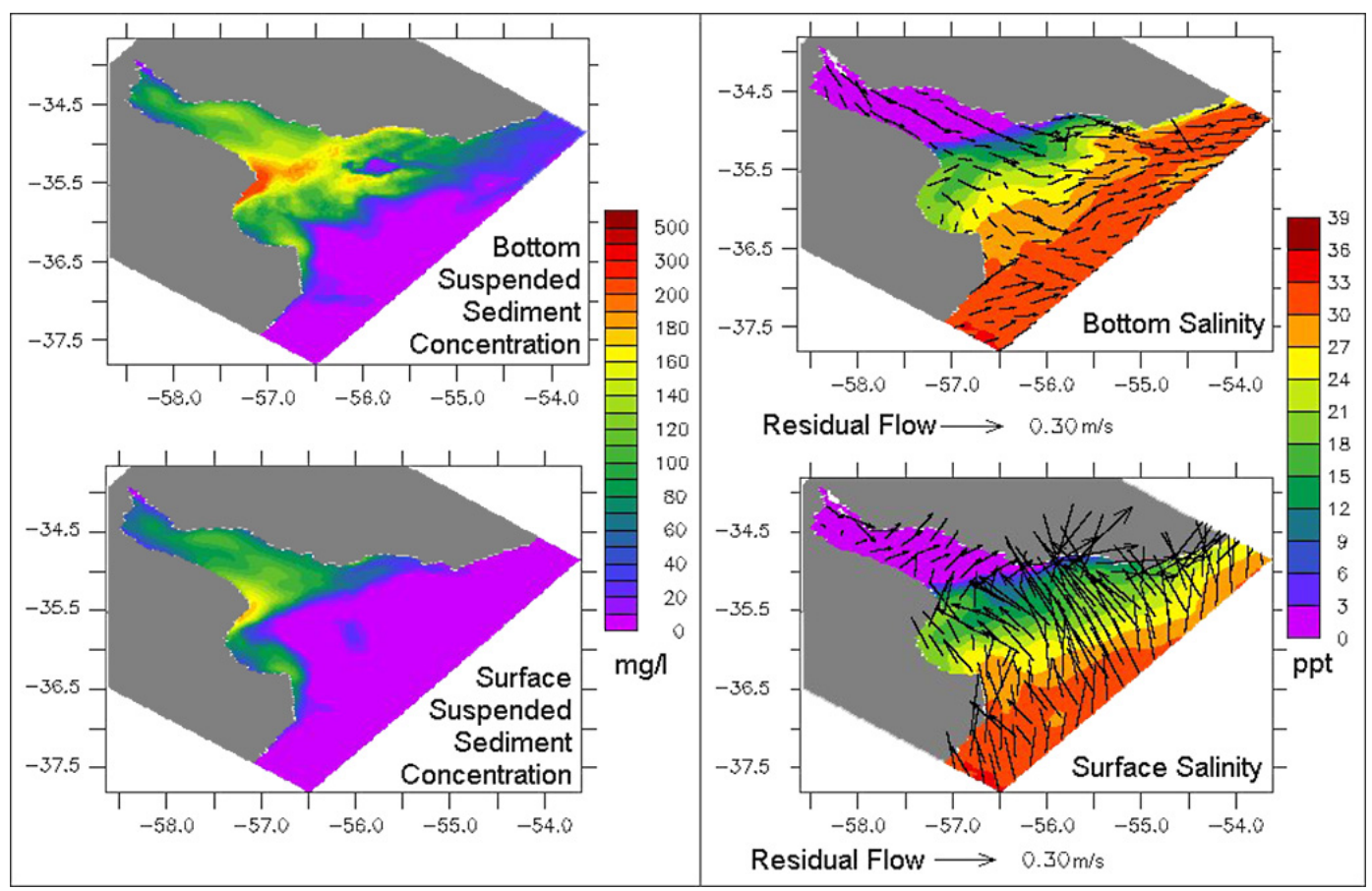

Fig. 5. Mean computed fields obtained over the 13-14 August 2010 period (storm conditions): bottom suspended sediment concentration (upper left panel), surface suspended sediment concentration (lower left panel), bottom salinity and residual flow (upper right panel), surface salinity and residual flow (lower right panel). 
simplifications (related with bottom shear stress, vertical turbulence, and mixing).

\section{Discussion}

Our results show that the model accurately reproduces the sediment concentration variability during both fair and stormy weather conditions in the intermediate and in the outer Río de la Plata. When only the river solid discharge advection is taken into account or when only the erosion of remote areas is considered in the model, neither the permanent suspended sediment concentration measured at TO during fair weather conditions nor the high values registered at TO or BB during August storm (Figs. 3 and 4) are reproduced. This modelling experiment helped to understand that the suspended sediment dynamic is dominated by sediment fluxes at the water/sediment bed interface. The threshold and rate of bottom sediment erosion were adjusted in order to reproduce peak sediment concentrations during storms but also during non-storm conditions when the tidal currents (astronomical and meteorological) erode bed sediment mainly at the intermediate Río de la Plata.

In addition, obtaining these results required to define a high value of critical stress for deposition (higher than the maximum bottom shear stresses in the entire Río de la Plata), which means that the suspended sediment is allowed to deposit during all times. This parameterization allows the reproduction of the abrupt sediment concentration drop observed in the measurements after the storms.

In Figs. 4 and 5 the mean fields of bottom and surface suspended sediment concentration, salinity and residual flow obtained with the model during fair weather and storm conditions are presented. The model allows to extend the TO and BB dynamic analysis to the entire Río de la Plata. The fine sediment dynamics at the Río de la Plata in the shortlytemporal scale depends on the region (intermediate vs. outer) and on the weather conditions (calms vs. storms). The intermediate zone is an area of vertically uniform turbidity levels because of the intense bed erosion due to tidal and fluvial flow; there are no-stratification conditions and during the storms the bed resuspension is intensified. In the outer zone there are low turbidity levels close to the bed trapped by the salinity vertical structure (stratified-conditions) during fair weather. However, during wave-storms there are high turbidity levels due to bed sediment resuspension, and there is no stratification salinity in the water column (mainly close to the intermediate zone and coastal areas) which allows vertical sediment mixing. After the storms, the sediment is redistributed by the 3-D currents patterns and the depositional areas depend on the salinity field structure. The described fair weather patterns are observed also in the turbidity and CTD profiles measured during the 5 campaigns at 26 stations.

\section{Conclusions}

The main characteristic of the fine sediments dynamics in the intermediate and outer zones of the RP were presented. The applied methodology includes data analysis, hydrodynamics numerical models implementation and calibration (MARS3D and SWAN) and a fine sediment model adjustment (MARS3D). The adjusted model reproduces the different time scales showed by the turbidity time series collected in measurement stations.

The main conclusion of the investigation is that the suspended sediment dynamics is mainly driven by water/bottom exchanges. The high frequency fine sediment dynamics in the Río de la Plata greatly varies according to space (intermediate vs outer zones) and time (weather conditions: calms vs. storms). The intermediate zone constantly exhibits high turbidity levels and is intensified during storms (increased resuspension). Turbidity levels in the outer zone remain low during fair weather, while storms also increase resuspension there, leading to high turbidity levels. After the storms, the sediment is redistributed by the 3-D currents patterns and the depositional areas depend on the salinity field structure.

Acknowledgements. The authors acknowledge the FREPLATAFFEM Project team composed by researchers from Argentina (SHN, CIMA, INA, INIDEP), Uruguay (SOHMA, IMFIA) and France (IFREMER), the governmental commissions CARP and CTMFM, and financial support provided by the FFEM and AFD agencies.

\section{References}

Ardhuin, F., Rogers, E., Babanin, A. V., Filipot, J.-F. O., Magne, R., Roland, A., van der Westhuysen, A., Queffeulou, P., Lefevre, J.M., Aouf, L., and Collard, F.: Semiempirical Dissipation Source Functions for Ocean Waves. Part I: Definition, Calibration, and Validation, J. Phys. Oceanogr., 40, 1917-1941, 2010.

Booij, N., Ris, R. C., and Holthuijsen, L. H.: A third-generation wave model for coastal regions: 1 . Model description and validation, J. Geophys. Res.-Oceans, 104, 7649-7666, 1999.

Dee, D. P., Uppala, S. M., Simmons, A. J., Berrisford, P., Poli, P., Kobayashi, S., Andrae, U., Balmaseda, M. A., Balsamo, G., Bauer, P., Bechtold, P., Beljaars, A. C. M., van de Berg, L., Bidlot, J., Bormann, N., Delsol, C., Dragani, R., Fuentes, M., Geer, A. J., Haimberger, L., Healy, S. B., Hersbach, H., Hólm, E. V., Isaksen, L., Kållberg, P., Köhler, M., Matricardi, M., McNally, A. P., Monge-Sanz, B. M., Morcrette, J. J., Park, B. K., Peubey, C., de Rosnay, P., Tavolato, C., Thépaut, J. N., and Vitart, F.: The ERA-Interim reanalysis: configuration and performance of the data assimilation system, Q. J. Roy. Meteor. Soc., 137, 553-597, 2011.

Dufois, F., Garreau, P., Le Hir, P., and Forget, P.: Wave- and currentinduced bottom shear stress distribution in the Gulf of Lions, Cont. Shelf Res., 28, 1920-1934, 2008. 
Fossati, M. and Piedra-Cueva, I.: A 3D hydrodynamic numerical model of the Río de la Plata and Montevideos coastal zone, Appl. Math. Model., 37, 1310-1332, 2013.

Framiñan, M. B. and Brown, O. B.: Study of the Río de la Plata turbidity front, Part 1: spatial and temporal distribution, Cont. Shelf Res., 16, 1259-1282, 1996.

Kalnay, E., Kanamitsu, M., Kistler, R., Collins, W., Deaven, D., Gandin, L., Iredell, M., Saha, S., White, G., Woollen, J., Zhu, Y., Leetmaa, A., Reynolds, R., Chelliah, M., Ebisuzaki, W., Higgins, W., Janowiak, J., Mo, K. C., Ropelewski, C., Wang, J., Jenne, R., and Joseph, D.: The NCEP/NCAR 40-Year Reanalysis Project, B. Am. Meteorol. Soc., 77, 437-471, 1996.

Lazure, P. and Dumas, F.: An external-internal mode coupling for a 3D hydrodynamical model for applications at regional scale (MARS), Adv. Water Res., 31, 233-250, 2008.

Le Hir, P., Bassoullet, P., and Jestin, H.: Application of the continuous modeling concept to simulate high-concentration suspended sediment in a macrotidal estuary, in: Proceedings in Marine Science, Elsevier, 229-247, 2000.

Le Hir, P., Cayocca, F., and Waeles, B.: Dynamics of sand and mud mixtures: A multiprocess-based modelling strategy, Cont. Shelf Res., 31, S135-S149, 2011.
López Laborde, J.: Geomorphological and geological setting of the Río de la Plata, The Río de la Plata, An environmental overview, 1-16, 1997.

Lyard, F., Lefevre, F., Letellier, T., and Francis, O.: Modelling the global ocean tides: modern insights from FES2004, Ocean Dynam., 56, 394-415, 2006.

Menéndez, A. and Sarubbi, A.: A Model to Predict the Paraná Delta Front Advancement, Workshop on Morphodynamic Processes in Large Lowland Rivers, Santa Fe, Argentina, 2007.

Migniot, C.: Tassement et rheologie des vases. Premiere partie, $\mathrm{La}$ Houille Blanche, 11-29, 1989.

Santoro, P. E., Fossati, M., and Piedra-Cueva, I.: Study of the meteorological tide in the Río de la Plata, Cont. Shelf Res., 60, 51-63, 2013.

Sepúlveda, H. H., Valle-Levinson, A., and Framiñan, M. B.: Observations of subtidal and tidal flow in the Río de la Plata Estuary, Cont. Shelf Res., 24, 509-525, 2004. 